\title{
The use and awareness of women's groups as sources of information in three small villages in Botswana
}

\author{
Neo Patricia Mooko \\ University of Botswana P.O. P/Bag 0022, Gaborone, Botswana \\ e-mail: mookonp@mopipi.ub.bw
}

\begin{abstract}
Received: 17th March 2002
Revised : 5th August 2002

A qualitative study was designed to investigate the use of women's groups as sources of family information for women residing in three rural villages in Botswana. The objectives of the study were to investigate situations that lead to information seeking, awareness of women's groups, the use of women's groups as sources of family information and the sources of information on women's groups. The study also captured the reasons for use and non-use of such organizations. A snow ball effect sampling procedure was used in selecting the participants of the study. The instruments of the study were focus groups and interview schedule. Descriptive statistics was used generated using SPSS for close ended questions. Responses from open-ended questions were analysed by grouping the data into themes. The results show that the respondents were aware of the existence of the various women groups both locally and nationally. However, they were not aware of the types of information and help that one could get from such organizations. Women were more familiar with the activities of the community-based women's groups as compared to the national women groups.
\end{abstract}

Keywords: women's groups, Botswana, rural women, user studies, information provision.

\section{Introduction}

The Population and housing Census of 200I shows that there are more women than men in Botswana. Most of the women reside in the non-urban areas. The 1991 Housing and census report indicated that female-headed households were greater than male-headed families in the rural areas. Women have diverse roles. In the female-headed families, women are solely responsible for all the matters concerning their families, such as the education of their children, health care and the management of the family estate and generate income for the family. Turning to illiteracy rates and poverty, adult females illiteracy was higher among women in the rural areas in 1993. The literacy rate of the non-urban women limits the types of sources that they could use when in need of information. With reference to income, $55 \%$ of the rural communities in Botswana live below poverty datum line (Botswana Human Development report, 1997). Therefore, most women in the rural communities are poor as they form the majority. In view of the diverse roles that women play in the society and the conditions that they face, it is important that they should be equipped and have access to information and relevant information sources that could help them in decision making and improving the welfare of the families.

\section{Literature review}

The information behaviours of professionals and the users of the library have enjoyed the attention of LIS researchers as shown by the works of Ellis, (1993), Leckie and Pettigrew, (1997). There is a dearth of studies on how women residing in the rural villages access information and the sources that they use. A few works including Mchombu (1996) and Kaniki (1995) had attempted to capture the information behaviours of the communities residing in southern Africa and some of the non-urban areas in Southern Africa. Mchombu (2000) looked at the information needs of small-scale businesses in Gaborone, Botswana. Besides the fact that this study was based in an urban, over half of the participants lacked knowledge of the formal sources of business information. It is generally known from the literature that the rural communities depend on oral information and depend on those who are close to them for information and help. The findings of studies mentioned did not target the usage of women's groups and the information behaviours of women in rural communities. The information behaviours of the women in the rural areas need to be investigated because they form a majority and have diverse roles that they play in the family including being partners, health providers and income generators.

Recent advances in the fields of telecommunication and computing have brought new ways of finding and accessing information and the establishment of information centres and organizations. The library, which is the traditional place for information, faces competition from such newly generated information organizations. One such type of organization is the women's group. Women through out the world have organized themselves into groups because they have a common interest or goal. Women's groups are divided in various ways. They are sometimes grouped as formal and informal groups. The formal groups have some linkages to the government and international organizations. The informal groups are characterized by being locally based and issue-oriented self -help groups. 


\subsection{Women's groups in Botswana}

Women's organizations play a significant role in national development. Generally their achievements include policy reforms, repealing and reformation of laws that disadvantage women, and the formulation of service-oriented projects geared at meeting the various needs of women. As stated in the Government of Botswana and United Nations Development Programme report of 1997, women's organizations in Botswana use the following approaches in implementing their activities:-

a) Programs that target women of low income with facilities and goods that they need for their families

b) Assumption that women are poor because of lack of capital, training, employment and land. Women's organizations help women to generate income through micro-lending schemes.

c) Strive for the eradication of discrimination against women.

The establishment of women's groups in Botswana dates back to 1962. There are sixteen women's organizations including women's wings of political parties. In 1993, some of the organisations came together to form the Women's Organisation Coalition. These groups disseminate business, legal health and political information. Women's groups in Botswana have been successful in representing the interests of Batswana women at international forums, challenging some of the laws that disadvantage women and instrumental in advocating for national policies that levels the grounds for the empowerment and incorporation of the women in national development. One of the major achievements of the women groups in Botswana is attributed to the Citizen law of 1982-1984, which was challenged at the Botswana High Court. Since Botswana's independence in 1966, everyone born in the country was a citizen. The Citizen law of $1982-$ 1984 amended the citizenship to birth by decent. As a result of this amendment, Batswana women who were married to foreigners could not pass their citizenship to their children. Women's groups were also successful in lobbying for the inclusion of women in political posts. Van Allen (2001:57) attributes the success of women groups in Botswana to 'a working liberal democratic system, an independent judiciary, a free press, rights for free speech and political organization, checks on corruption, and the clear legitimacy of a civilian government that depends for its continued power on free and fair elections".

\section{Methodology}

This qualitative study utilized interview schedule and focus group as data collection instruments. The interview schedule was based on an instrument developed by Chen and Hernon in 1982 that utilised the critical incident technique. One focus group was held in each of the three villages, which were the sites for the study. Questions for the focus group were aligned with the research questions. The purpose of the focus group was to explore their feelings and learn more about their perceptions of women's groups as sources of family information. The interview schedule had both structured and opens ended questions. The respondents of the study were divided into two groups, opinion leaders and women residing in the Makwate, Modipane and Paje in Botswana. The respondents were married women, single women who were heads of households and opinion leaders. Purposive sampling, as a non-probability sampling procedure, also known as snowball effect was used. This sampling procedure has been chosen because the respondents had to meet certain predefined criteria (Patton, 1990). For example they must have a family, either married or single head of a household. The participants were asked to suggest the names of other women who could be interviewed and also the opinion leaders in the village.

A total of 60 women, 20 from each village formed the population of the study. The researcher carried out the interviews with the respondents in their homes. The questions were read to the respondents in Setswana which is the national language spoken by over $90 \%$ of the citizens of Botswana. The researcher recorded the responses of the participants. The interview was based on a situation in which the participant had to look for information for herself or a family member.

For closed ended questions, descriptive statistics was generated using the Statistical Package for the Social Sciences. Open-ended questions were analyzed by grouping the responses into themes. Direct quotations were used to show the insider's perspective. Feterman (1998:20) stated that the insider's perception of reality is instrumental to understanding and accurately describing situations and behaviors. The preliminary analyses of the data were done as the researcher continued with the interviews.

\section{Results: Gaining entry to research sites}

The researcher is a citizen of Botswana and is fluent in Setswana, the national language. The researcher did not anticipate any cultural conflicts as she was born and raised in the culture of the respondents. The researcher also knows village life as she was born and raised in one of the villages in Botswana. Gaining entry into the village involved a visit to the tribal administration office to introduce the researcher and the project to the village chief. All the chiefs in the three villages 
gave their permission to speak to the village women. The challenge was gaining entry into the homes of the potential respondents and ascertaining whether they would agree to talk and trust enough to open up. Batswana' believe that all roofs leak. Therefore, like most societies, situations in the homes may be kept as family secrets and may not be shared with the villagers let alone a stranger.

\subsection{Description of the sites of study}

\section{Makwate village}

Makwate is located in the central district. It is situated about 60 kilometers to the east of Mahalapye, one of the largest urban villages in Botswana. The population of Makwate in $200 \mathrm{I}$ was I59I (Central Statistics Office, 2002). There was a health post, primary school and the tribal administration office. A nurse and community health officer manned the health post. Both the health post and the tribal administration offices do not open for the public during the weekend and on public holidays. Botswana government offices do not normally open during the weekend and on public holidays. However, in the urban centres and large villages they are always open to serve those communities.

\section{Modipane Village}

Modipane is situated in the southern part of Botswana. It is about 30 kilometers east of Gaborone City. The 200 I Population and housing Census stated the population of this village as 2423. A tarred road runs through the village. There was a health post, a postal agency, and a primary school and tribal administration office. One nurse and a community welfare officer staffed the health post. This facility does not offer services during the weekend and during public holidays. One person also staffed the postal agency. The staff of the tribal administration includes the clerk of the court, the village local police officer and the village chief. The tribal administration offices also does not open during the weekend. However, in case of an emergency, the villagers the local police office is available to assist. Modipane was the nearest to an urban centre. Modipane is accessible by public transport that runs to and from Gaborone City throughout the day. There were no grocery shops in the village except for small general dealers, which offered a limited variety of foodstuffs. The children traveled 15 kilometers every morning to attend the nearest junior community secondary school.

Paje village

Paje village is situated in the Central District, 22 kilometers north of Serowe village, which is one of the major villages in Botswana. The population of Paje as stated in the 200I Population and Housing census was 2088 (Central Statistics Office, 2002). A tarred road to Orapa, a diamond mine town, runs through the village. There was a health post, one primary school, and tribal administration. A minibus that made several trips to and from Serowe provided public transport. There was no shopping centre in the village. Small general dealers, bars and phone shops were located in one place, which served as a business location in the village.

4.2. Description of the respondents

Out of 60 participants, half of the respondents were single heads of households, $46 \%$ were married, and $3.34 \%$ were divorced and widowed. When asked their educational level, $28.3 \%$ were stated that they were illiterate, $55 \%$ had been to school for at most seven years, and $16.7 \%$ had been to school for nine years. The participants who had never been to school were aged at least 60 years. The respondents were asked the sources of income. They mentioned the following as the sources of income for their families, running a home based kiosk, brewing and selling of traditional beer, selling of new and used clothing, selling farm produce and prepared food. In cases where the respondent mentioned more than one source of income, the one that brought in more money was recorded. The informants also mentioned that they were dependent on the money that children and their spouses provided.

4.3. Situations that lead to information seeking

The respondents were asked to think of a situation in which they had to look for information for themselves or a family member in the last two months. The women mentioned situations shown in Table I below.

I. The plural for the citizens of Botswana. 
Table I. Situations that led the respondents to look for information $N=60$

\begin{tabular}{l|l|l}
\hline Situations & Frequency & Percentage \\
\hline Illnesses (family, self) & 22 & 38.3 \\
Basic needs (clothing, food) & 8 & 13.3 \\
Finances to start a business & 8 & 13.3 \\
Lack of employment & 7 & 11.7 \\
Agricultural activities & 5 & 8.3 \\
Child maintenance & 3 & 5.0 \\
Need for training & 2 & 3.3 \\
Family violence & 2 & 3.3 \\
In need of official documents & 1 & 1.7 \\
\hline
\end{tabular}

Table I suggests that sicknesses within the family were the most frequent situations in which the women in the three rural villages in Botswana faced. The findings suggest that information pertaining to child maintenance, further training and family violence were the least common among the participants.

\subsection{Awareness of the women's organizations}

The respondents were asked whether they were aware of any women's groups. Only twelve $(25.2 \%)$ stated that they were not aware of the women's groups while $74.8 \%$ of all the respondents were aware of some form of women's groups either locally or nationally.

The women mentioned the following as an indication of their awareness of the functions of women's organizations:

I.One can get a small loan from Women in Finance, Botswana

2.They help in family disputes by telling the women what to do to protect themselves.

3.They can help a woman if the husband no longer lives in the matrimonial home.

4.I have heard that if one is not careful, they can influence you to separate with your spouse.

5. They teach women on how to take care of the sick at home.

6.Women's wings of different political parties teach women on how to vote. I have also heard that one women's organization encourages women to stand for political posts.

7.Yes, I have heard of them. These people just stay in Gaborone where you come from.

8. They teach about equality between men and women.

4.5. Community based women's groups in the villages

The respondents revealed that even though some of the national women's organizations had reached the rural villages, the village-based women's groups were the most valuable source of information in many aspects of life. These groups were diverse. They were the sources of financial information and also served as avenues through which one gets to know what was going on in the village. For example, whose son or daughter was sick to near death, the days and times for the funeral in the village, they were also sources of information on how to handle some the problems at home. Information on job opportunities like when a manufacturing company or a supermarket was hiring casual laborers could also be obtained through such groups. These groups include the Home based Care, Aids Committee, Crime Prevention Committee and women's wings of political parties. The other groups were churches based and a few women formed others on their own. The main purpose of such groups was usually to help each other through monetary contributions. Such schemes brought the women together and were a vital source of information as they continued to interact.

Home based care members were women who had volunteered to help in caring for the sick in the village. These women helped by cleaning the houses, cooking, doing the laundry and picking the medication from the village health post. They also went to the clinic to pick the medication for the sick. The Aids Committee mainly taught the villagers about HIV/AIDS.

One of the respondents told the researcher about "rotating" money schemes that the women in the village were involved in. Her group was made up of four women. This was not the only such group in the villages. The respondents informed the researcher of other groups consisting of three to six women. The members of the group made monthly contributions, which were in turn given to one member of the group at the meeting. That is, in a group of four women, after four months each would have received the contributions. The success of such a group was dependent on trust and the close relationship between among the members. The group members were usually close friends and relatives. These types of groups were present in all the three villages. 
In a different village, one of the respondents who brewed and sold traditional beer told the researcher about yet another group of which she was a member. This was a group of women who were also brewing and selling traditional beer in their yards. Each of the members contributed some money on the day one of the members was selling beer. The reason was to increase the takings for that day.

The other groups that indirectly served as sources of information were the burial societies in the village. These groups comprised of both men and women. Burial societies were mentioned here because women held key positions such as treasurers and secretaries. The members made monthly contributions to a fund. Members were allowed to register a given number of beneficiaries whom the society would make payments when they passed away. The payments covered the funeral expenses such as the purchase of a coffin. These groups had regular meetings, which served, as source of information through conversations and discussion.

4.6. Sources of information on women's groups.

The respondents were asked how they heard of women groups in the village or nationally. The following table lists the channels of information on women's groups mentioned by the rural women in Makwate, Modipane and Paje.

Table 2. Sources of information on women's groups: all the respondents $\mathrm{N}=60$

\begin{tabular}{lll}
\hline Sources & Frequency & Percentage of responses \\
\hline Other Women in the village & 18 & 26.9 \\
Radio & 16 & 23.9 \\
Friends & 12 & 17.9 \\
Women's groups & 9 & 13.4 \\
${ }^{\text {a} K g o t l a ~ M e e t i n g ~}$ & 5 & 7.4 \\
Political gathering & 2 & 3.0 \\
Newspaper & 2 & 3.0 \\
Clinic & 2 & 3.0 \\
Relatives & 1 & 1.5 \\
Total & 67 & 100 \\
\hline
\end{tabular}

a. A kgotla is a traditional place where the villagers addressed and consulted by the village chief, government officials and political representatives. It also serves as a traditional court.

Note. Women's groups: the respondent heard of other women's organization while attending a meeting of another village based group.

The total number of responses is more than 60 because some of the respondents mentioned more than one source. Other women in the villages refer to those who were not described as friends.

Ordinary members of the village, the national radio station and friends were the most common sources of information on women's groups as shown in Table 2. The findings of this study suggest that political gatherings and printed matter were the least mentioned sources of information on women's groups in these villages.

The respondents were asked whether they think women's organizations were possible sources of information in their situations. Out of the 60 participants, (31.7\%) believed that women's groups could provide them with information in their situations. Forty-five percent of the respondents indicated that they do not believe that women's groups could provide answers to their questions. The remaining $(23.3 \%)$ indicated that they do not know. The respondents did not think that the women's groups were in a position to provide them with specific information in their situations. The researcher understood the women to mean that the information that they needed was specialized, considering the fact that most of the situations leading to information seeking were health related. One other reason advanced here was that the respondents did not about the women's groups. Some did not know what information could be obtained from the women's groups.

4.7. Reasons for the use and non-use of women's groups for information

The respondents differentiated between the community based groups and the national women's organizations. The reason advanced for the use of the two types of women's groups was that they provided right information needed by the women. The community-based groups were more meaningful to the informants. These groups were based in the village. Local women knew the other women who held positions in these groups. In some cases women in this study were 
themselves members of the village-based groups. The respondents were familiar with the activities of the communitybased groups and identified themselves more with them. The community-based groups provide a non-threatening environment to them. One respondent however stated she was reluctant to seek information from the village-based groups because " they freely talk about other people diseases in the village."

The main reason for the non-use of national and international women's organizations was because rural women were ignorant of their existence, and they were not conversant with their objectives. In addition, lack of use was related to the fact that women in the rural areas were not aware of the types of information that such organizations provided to the women of Botswana. For those that have members in the village they were not aggressive in selling the ideas of their organizations. This is a challenge for women organizations to start educating the general public about their aims, activities and the information that they disseminate.

The other reason for the non-use was misinformation. For example, some women mentioned that if one was not careful in dealing with some of the organizations they might ill advise you. There tends to be some incorrect information that some rural women have been exposed with respect to what some of the national and international women's organizations do. For example, the issue of gender equality was one that seems to have been totally misunderstood and in the process these organizations that advocate gender equality were seen to be enemies of family stability. It is these kinds of perceptions that tend to make some women to keep away from such organizations.

The services and operations of one particular woman's organization loans seem to be a deterrent in using the organization. Bearing in mind that these communities seem to first find out information from neighbors and friends, the negative information received may have a negative effect in the likelihood of women approaching the women's organization for further information. This is what one respondent had to say about one of the women's organizations where she applied for a loan:

The cheques arrived when we had already given up. To our surprise the first installment was due in the next two weeks. They do not give us a chance to sell so that we can pay back. I also feel that the repayment is too high. One other disadvantage about the organization is that they only lend money to groups of five. If one of the group members defaults, then the entire group cannot apply for second loan until the other members has finished repaying the loan.

I feel the organization is not good because an individual cannot get help from the organization.

The length of processing the loans may also affect the usage of the organization, which reaches out to the women through financial loans.

One of the problems pointed out by the women regarding this particular organization was that one couldn't get a loan to start a new business. They wanted women who were already in business. Therefore women who were not in business were reluctant to find more information about the organizations.

\subsection{Focus group}

The participants in the focus group were asked whether they think the women's organizations were possible sources of information in the family situations that the women in the village were facing. The focus group believed that women's organizations have a lot to offer to the women in the rural areas. They were disappointed by the fact that women's groups seem to be concentrated in the city and the larger villages and do not reach out to the women in the small villages. Few of the women's organizations that they heard about came to their villages.

The participants in the discussion group pointed out that the way in which the women's organizations communicate with the women was not effective. Even though some of these organizations visited the village, they never made any follow-ups after the meeting. In addition, these organizations did not leave any representatives in the villages or at least identify some people who could act as their representatives. Consequently, no one was left behind to attend to the questions that the people might be having after the mass address. They felt this was important as some of the women may not feel free to ask questions during the meeting. As a result, there is a need to have officers who could talk to the women privately. It was also pointed out that most the people living in the rural villages have a low literacy rate. As a result, they might not grasp some of the issues raised during the mass address.

\section{Discussion}

The interpersonal sources played an important role in the communication of information to and among the rural women (see Table 2). Interpersonal information sources thrive on oral communication. Information networks and informal information sources are convenient, allow easy access to information and give immediate response. The members of the networks know each other and trust each other because they have been together for sometime.

The radio was the most popular media that provided information on women groups and their activities (see Table2). In addition, the radio also sometimes provided information relevant to the situations that the respondents were facing. The programs tailored for the women include interviews with successful businesswomen, discussions on vocational 
institutions where the women could learn diverse skills such as weaving, knitting, handcraft and may more. In such programs problems of teenage pregnancies are also discussed and the young are encouraged to go back to school or continue their education through distance learning. There are also programs on HIV/AIDS aired by private radio stations.

The sources of information for the rural women suffer from lack of variety and were limited numerically. One of the contributing factors is the educational level of the respondents, which obviously point to a population that was unlikely to find information by reading. In actual fact, some of them could not read at all. The women also obviously lacked the skills needed to effectively seek information on their own. Even though this was the case, the women themselves realized the importance of information as they managed to visit some of the national women's organization located in the urban villages. Based on the fact that they were not exposed to a variety of information sources, they were able to make suggestions, which clearly indicated that they had a need to access information from a central point. For example when asked what could be done to help women in the village find information, the respondents suggested that posters be placed around in the village, at the village health post and tribal administration offices. These were places frequented by the villagers.

In the rural communities, the village-based women's group was important sources of information compared to national women's groups. These groups were formed by the women themselves and some of the respondents and opinion leaders served in the committees. The women were aware of the national women's organizations over the media such as the radio and their occasional visit to the kgotla. The focus group raised some concerns in the form of lack of representation of the national's group in the rural communities and their mode of communicating information, which they felt was not suitable for rural women. Gordon (1996) and Osirim (1998) rightly pointed out that national women's organizations generally reflected the concerns of the elite women even when they state that they were designed to meet the needs of the masses. Although one would not like to undermine the efforts of the women's organization, which had already visited the rural women, the above statement by Gordon and Osirim ties with the findings of this study.

Only six women had approached the national women's organizations. These organizations were largely viewed as outsiders and sometimes with suspicion. It is the opinion of this researcher based on the responses of the women that they felt one should be very careful in their dealings with the "outside' women's groups. Women's organizations campaigning for gender equality have to work very hard to earn the support of the "traditional" Motswana woman who views their spouses as sole providers and heads of the household. They also have to win the trust of the men so that they could allow their wives to participate in women activities and thus get access to information and help provided by the women's groups.

\section{Conclusion}

The study suggests that the respondents as sources of information least used women's groups. The opinion leaders however indicated that the women's groups could play an important role in providing information to the rural women in Botswana. The women in the three villages were aware of the existence of women's groups and had some general knowledge of what they stand for. The national women groups could function better if they collaborate with the community-based groups and take advantage of the already existent relation between the groups and the women. It is also suggested that the established channels sources of information on women's groups, such as the radio and verbal communication, be used more as the women are already comfortable with them. This could be done through radio programs and workshops. A successful and effective information provision to the women would take expanding opportunities of information provision to the women themselves. Through their own active and collective participation they will access the information needed by their families and in making informed decisions.

\section{References}

Central Statistics Office. 200I. Population and housing census: populations of towns, villages and associated localities. Gaborone, Government printer.

Chen,C. \& Hernon,P. 1982. Information seeking: assessing and anticipating user needs. New York: Neal-Schuman.

Ellis, D. 1993. Modelling the information seeking patterns of academic researchers: a grounded theory approach. Library Quarterly, 63: 469-486.

Fetterman, D. 1998. Ethnography: step by step. $2^{\text {nd }}$.ed. Thousands Oaks, CA: Sage Publications.

Gordon, A.A. 1996. Transforming capitalism and Patriarchy: gender and development in Africa. Boulder, Connecticut: Lynne Rienner Publishers.

Government of Botswana and United Nations Development Programme (1998) Botswana Human Development Report, 1997. Gaborone. Government Printer.

Kaniki, A. 1995. Exploratory study of the information needs in Kwa-Ngwanese (Natal) and Qumbu (Transkei) communities of South Africa. South African Journal of Library and Information Science, 63: 9-18 
Leckie, G.J. \& Pettigrew, K.E. 1997. A general model of the information seeking of professionals: role theory through the back door? In Vakkari,R. , Savolainen, R \& B. Dervin (eds). Information seeking in context: proceedings of the international conference on research in information needs, seeking and the use in different contexts. London: Taylor Graham, 99-I I0.

Mchombu, C.M. 2000. Information needs of women in small businesses in Botswana. International Information and Library Review, 32: 39-67.

Mchombu, K. 1996. A survey of information needs for rural development. Resource Sharing and Information Networks, I2: 75-8I

Osimiri, M.J. 1998. Making good on commitments Vehicles for change and empowerment: NGOs and empowerment for women in contemporary Zimbabwe. Women Studies International Forum, 24(2): I67-I80.

Patton, M.Q. 1990. Qualitative evaluation and research methods. ( $2^{\text {nd }}$. ed.) Newbury Park, Sage publications.

Van Allen, J. 200I. The women's rights movements and a measure of African democracy. Journal of Asian and African Studies, 36 ( I): 39-63. 